\title{
Peningkatan Kemampuan Mentrasformasi Cerpen Menjadi Naskah Drama Menggunakan Metode Diskusi Siswa Kelas VIII-A SMP Kristen Hosana T.P 2018/2019
}

\author{
Santa Nova Manik \\ Ramadhan Saleh \\ Universitas Prima Indonesia \\ Santanova96@gmail.com
}

\begin{abstract}
ABSTRAK
Permasalahan yang dikaji dalam penelitian ini adalah: proses, hasil, serta peningkatan pembelajaran kemampuan mentransformasi cerpen menjadi naskah drama menggunakan metode diskusi kelas VIII-A SMP Kristen Hosana tahun 2018/2019. Jenis penelitian ini adalah deskriptif kualitatif dengan menggunakan metode penelitian tindakan kelas, yang terdiri dari siklus I, dan siklus II. Subjek penelitian ini adalah siswa VIII-A SMP Kristen Hosana yang terdiri dari 11 siswa laki-laki dan 11 siswa perempuan. Pengambilan sampel dilakukan dengan purposive sampling (sampel bertujuan). Hasil penelitian ini menunjukkan bahwa adanya peningkatan kemampuaan mentransformasi cerpen menjadi naskah drama menggunakan metode diskusi. Hasil tes yang dilakukan pada siklus I, ketuntasan klasikal yang diperoleh sebesar 36,36\%. Hasil tes pada siklus II mengalami peningkatan menjadi $77,27 \%$. Berdasarkan data tersebut dapat diketahui bahwa peningkatan pada tes kemampuan mentransformasi cerpen menjadi naskah drama pada siklus I-siklus II sebesar 40,91\%.Berdasarkan uraian tersebut, maka dapat disimpukan bahwa mengunakan metode diskusi dapat meningkatkan kemampuan mentransformasi cerpen menjadi naskah drama siswa VIII-A SMP Kristen Hosana tahun 2018/2019.
\end{abstract}

Kata kunci: Diskusi Kelas, Mentransformasi cerpen, drama.

PENDAHULUAN

Keterampilan pembelajaran berbahasa mencakup empat aspek, yaitu keterampilan menyimak, berbicara, membaca, dan menulis. Marwoto (dalam Dalman 2014: 4) menjelaskan bahwa menulis adalah mengungkapkan ide atau gagasannya dalam bentuk karangan secara leluasa. Menulis teks drama dapat dibuat melalui teks cerpen. Dengan cara mengubah teks cerpen menjadi teks drama. Melalui teks cerpen, peserta didik diharapkan mampu mengungkapkan gagasan, ide ataupun berimajinasi dalam membuat sebuah karya sastra yaitu dapat menulis teks drama sesuai dengan standar kompetensi dalam silabus bahasa Indonesia kelas VIII.

Dalam pembelajaran Bahasa Indonesia terdapat standar kompetensi yang berisi menulis drama pada silabus Bahasa Indonesia kelas VIII. Nilai KKM yang ditentukan sekolah adalah 75. Ada beberapa hal yang menjadi penyebab kurang berhasilnya pembelajaran menulis teks drama diantaranya adalah rendahnya minat siswa dalam menulis teks drama, disebabkan karena siswa tidak memiliki 
keberanian dalam mengungkapkan ide, kosakata yang dimiliki masih kurang, niat belajar yang dimiliki masih rendah, rendahnya pengetahuan siswa dalam sastra terutama menulis teks drama, sarana dan prasarana di sekolah kurang memadai, penggunaan metode yang terfokus pada satu metode dapat membuat peserta didik merasa bosan saat proses pembelajaran di kelas.

Metode yang dapat digunakan dalam meningkatkan keterampilan menulis teks drama adalah dengan menggunakan metode diskusi. Killen (dalam Sanjaya 2007:154), metode diskusi adalah metode pembelajaran yang menghadapkan siswa pada suatu permasalahan. Dengan menggunakan metode diskusi, para peserta didik dapat lebih mudah menulis teks drama melalui teks cerpen yang diberikan guru kepada peserta didik.

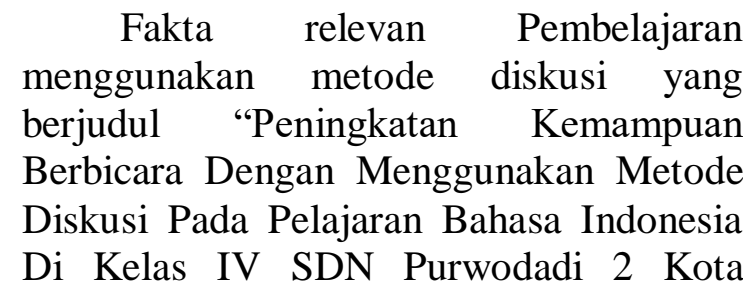
Malang". Hasil penelitian yang diperoleh adalah sebagai berikut; . Pada pra tindakan rata-rata nilai siswa $60,32 \%$, Pada siklus I rata-rata nilai siswa $66,77 \%$, dan Pada siklus II rata-rata nilai siswa $79,35 \%$, dengan kata lain pada siklus II ini sudah mencapai ketuntasan belajar yang diharapkan. Dapat disimpulkan dari tindakan- tindakan yang menggunakan metode Diskusi dapat dilihat di atas pembelajaran mulai dari pra tindakan sampai siklus I dan siklus II selalu meningkat. Sehingga dikatakan peneliti menggunakan metode Diskusi ini dikatakan berhasil.

\section{METODE PENELITIAN}

Penelitian ini akan dilaksanakan di SMP Kristen Hosana pada kelas VIII-A
SMP Tahun Pelajaran 2018/2019. Kecamatan Medan Deli, Kabupaten Deli Serdang. Penelitian ini dilaksanakan pada semester genap Tahun Pelajaran 2018/2019. Penelitian ini menggunakan penelitian tindakan kelas. Menurut Sugiyono (2014: 3) mengatakan bahwa "Pendekatan penelitian merupakan cara ilmiah untuk mendapatkan data dengan tujuan dan kegunaan tertentu. Penelitian ini dilakukan dengan menggunakan pendekatan Penelitian Tindakan Kelas (PTK)". Menurut Arikunto (2013: 134) mengatakan "Penelitian tindakan kelas termasuk penelitian kualitatif, karena menggali informasi lebih rinci”.

Subjek penelitian ini adalah siswa kelas VIII-A SMP Kristen Hosana Tahun Pelajaran 2018/2019 yang berjumlah 22 siswa, dengan siswa11 laki-laki dan 11 siswa perempuan. Dan Objek dalam penelitian ini adalah penerapan metode diskusi kelompok untuk meningkatkan keterampilan menulis dalam mengubah teks cerpen menjadi teks drama pada subpokok bahasan menulis di kelas VIIIA SMP Kristen Hosana Tahun Pelajaran 2018/2019.

Dalam penelitian ini data yang digunakan yaitu ata siswa dan data yang diperoleh dari guru kelas VIII-A SMP Kristen Hosana. Pengambilan data dilakukan di ruangan kelas VIII-A SMP Kristen Hosana. Sumber data diperoleh dari tempat penelitian yang sudah ditentukan atau mendapat perlakuan tindakan penelitian yakni di kelas VIII-A SMP Kristen Hosana yang berupa informasi dari guru dan siswa kelas VIII-A SMP Kristen Hosana melalui hasil wawancara, hasil tes belajar siswa pada pokok pembahasan mengubah teks cerpen menjadi teks drama mata pelajaran Bahasa Indonesia melalui metode diskusi kelompok. Teknik pengumpulan data yang digunakan, yaitu wawancara, observasi, tes, dan dokumentasi. 


\section{HASIL DAN PEMBAHASAN}

Penelitian tindakan kelas ini dilakukan di kelas VIII-A SMP Kristen Hosana tahun 2018/2019. Dengan jumlah siswa 22 siswa yang terdiri dari 11 siswa laki-laki dan 11 siswa perempuan. Hasil penelitian ini diperoleh dari tahap pelaksanaan tindakan pada tahap siklus I, dan tahap siklus II yang terdapat pada penilaian hasil tes. Hasil tes tindakan siklus I dan II merupakan hasil tes kemampuan mentransformasi cerpen dengan adanya perlakuan ataupun tindakan mengajar dengan menerapkan metode diskusi. Kemudian, pada hasil tes terdapat data observasi, wawancara, dan dokumentasi berupa foto pada saat berlangsungnya proses pembelajaran mentransformasi cerpen menjadi naskah drama. Proses pembelajaran yang sudah dilaksanakan oleh peneliti yaitu mentransformasi cerpen menjadi naskah drama menggunakan metode diskusi siswa kelas VIII-A SMP Kristen Hosana T.P 2018/2019. Hasil penelitian ini terlihat dari penilaian tes yang diberikan kepada siswa untuk dikerjakan di setiap tahap-tahap kegiatan pembelajaran yang telah dilakukan penelitian yaitu siklus I, dan siklus II.

Tahapan tindakan pembelajaran siklus I merupakan tindakan awal untuk memperbaiki dan meningkatkan kemampuan mentransformasi cerpen pada siswa kelas VIII-A SMP Kristen Hosana tahun 2018/2019. Pada pembelajaran mentransformasi cerpen menjadi drama siklus I ini peneliti menerapkan metode diskusi yang terdiri dari hasil tes. Kedua hasil penelitian tersebut meliputi nilai tes kemampuan mentransformasi cerpen menjadi drama siswa dan kegiatan pembelajaran guru beserta siswa selama berlangsungnya proses pembelajaran di kelas. Kemudian hasil analisis tindakan pembelajaran ini akan dijadikan sebagai refleksi bagi peneliti pada tindakan siklus pembelajaran selanjutnya.
Kegiatan penelitian pada siklus I dilaksanakan dalam satu kali pertemuan yang terdiri dua jam pembelajaran dengan alokasi waktu (2x40 menit). Adapun deskripsi tahap kegiatan pembelajaran pada siklus I, yaitu penelitian siklus I ini dilaksanakan oleh peneliti di kelas VIII-A dalam satu kali pertemuan yang diikuti oleh 22 siswa kelas VIII-A SMP Kristen Hosana. Pelaksanaan siklus I ini dilakukan pada hari Sabtu, 27 April 2019. Pada penelitian ini yang berperan sebagai guru dalam menyampaikan materi pembelajaran adalah peneliti. Hasil tes kemampuan menulis puisi pada siklus I persentase siswa yang tuntas adalah $36,36 \%$ dan persentase siswa yang tidak tuntas adalah 63,63\%..Tetapi masih belum mencukupi untuk memenuhi kriteria yang diharapkan yaitu $75 \%$. Untuk itu perlu diadakan pelaksanaan siklus II.

\begin{tabular}{|c|c|c|}
\hline $\begin{array}{c}\text { Rentang } \\
\text { Nilai }\end{array}$ & $\begin{array}{c}\text { Banyak } \\
\text { Siswa }\end{array}$ & $\begin{array}{c}\text { Nilai } \\
\text { Persentase } \\
\text { KKK }\end{array}$ \\
\hline $85-100$ & - & \multirow{6}{*}{$\begin{array}{l}\text { Nilai } \\
\text { persentase } \\
\text { Kriteria } \\
\text { Ketuntasan } \\
\text { Klasikal } \\
\text { (KKK) } \\
\text { kemampuan } \\
\text { mentransfor } \\
\text { masi cerpen } \\
\text { menjadi } \\
\text { naskah } \\
\text { drama pada } \\
\text { siklus I } \\
\text { adalah } \\
\text { 36,36\%. }\end{array}$} \\
\hline $75-84$ & 8 & \\
\hline $65-74$ & 4 & \\
\hline $55-64$ & 1 & \\
\hline$<54$ & 9 & \\
\hline$\sum$ & 22 & \\
\hline \multicolumn{3}{|c|}{$\begin{array}{l}\text { Berdasarkan hasil tes kemampuan } \\
\text { mentransformasi cerpen menjadi naskah } \\
\text { drama yang dilaksanakan pada siklus I } \\
\text { dapat diketahui bahwa, masih perlu } \\
\text { diadakan tindakan lanjutan guna } \\
\text { memperbaiki nilai yang ada agar dapat } \\
\text { mencapai nilai KKK yaitu } \geq 75 \% \text {. Oleh }\end{array}$} \\
\hline
\end{tabular}


karena itu, peneliti melakukan siklus II agar dapat meningkatkan nilai kemampuan mentransformasi cerpen menjadi naskah drama. Pada siklus II siswa yang tuntas adalah 17 siswa dengan persentase 77,27 $\%$. Dan siswa yang tidak tuntas sebanyak 5 siswa dengan persentase $22,72 \%$.

Tabel 1 Perolehan Persentase Kriteria Ketuntasan Klasikal Tes pada Siklus II

\begin{tabular}{|c|c|c|}
\hline $\begin{array}{c}\text { Rentang } \\
\text { Nilai }\end{array}$ & $\begin{array}{l}\text { Banyak } \\
\text { Siswa }\end{array}$ & $\begin{array}{c}\text { Nilai } \\
\text { Persentase } \\
\text { KKK }\end{array}$ \\
\hline $85-100$ & 4 & Nilai \\
\hline $75-84$ & 13 & persentase \\
\hline $65-74$ & - & Kriteria \\
\hline $55-64$ & - & Ketuntasan \\
\hline$<54$ & 5 & $(\mathrm{KKK})$ \\
\hline$\sum$ & 22 & $\begin{array}{c}\text { kemampuan } \\
\text { mentransfor } \\
\text { masi cerpen } \\
\text { menjadi } \\
\text { naskah } \\
\text { drama pada } \\
\text { siklus I } \\
\text { adalah77,27 } \\
\% \text {. }\end{array}$ \\
\hline
\end{tabular}

Untuk memberikan gambaran yang jelas atas pencapaian hasil penelitian yang telah meningkat pada siklus I dan siklus II dari hasil tes dalam pembelajaran menyimpulkan teks hasil observasi dapat dilihat melalui tabel 4.9 sebagai berikut.

Tabel 2 Rekapitulasi Peningkatan Hasil Nilai Tes Kemampuan mentransformasi cerpen menjadi naskah drama pada Siswa di Kelas VIII-A Kristen Hosana tahun 2018/2019

\begin{tabular}{l|c|c|c}
\hline $\begin{array}{l}\text { Rentang } \\
\text { Nilai }\end{array}$ & $\begin{array}{l}\text { Siklus } \\
\text { I }\end{array}$ & $\begin{array}{l}\text { Siklus } \\
\text { II }\end{array}$ & Peningkata \\
\hline $85-100$ & 0 & 4 & 4 \\
\hline $75-84$ & 8 & 13 & 5 \\
\hline $65-74$ & 4 & 0 & \\
\hline $55-64$ & 1 & 0 & \\
\hline$<54$ & 9 & 5 & \\
\hline $\begin{array}{l}\text { Nilai } \\
\text { Tertinggi } \\
\text { Tes }\end{array}$ & 84 & 92 & 8 \\
\hline $\begin{array}{l}\text { Nilai } \\
\text { Terendah } \\
\text { Tes }\end{array}$ & 20 & 20 & \\
\hline $\begin{array}{l}\text { Persentase } \\
\text { Ketuntasan } \\
\text { Klasikal Tes } \\
(\%)\end{array}$ & 36,36 & 77,27 & 40,91 \\
\hline $\begin{array}{l}\text { Persentase } \\
\text { Yang Tidak } \\
\text { Tuntas Tes } \\
(\%)\end{array}$ & 63,63 & 22,72 & \\
\hline
\end{tabular}

Adapun hasilnya pada kegiatan pembelajaran siklus I yang peneliti lakukan di kelas VIII-A memperoleh siswa yang lulus mendapatkan standar $\mathrm{KKM} \geq 75$ hanya 8 siswa $(36,36 \%)$. Sedangkan siswa yang belum lulus mendapatkan nilai $\geq 75$ ada 14 siswa $(63,63 \%)$. Pada proses siklus I indikator keberhasilan pada penilaian KKK siswa belum mencapai atau melampaui $\quad \geq 75 \%$ sehingga dapat disimpulkan belum tercapai.

Melihat dari siklus I tersebut perlu dilakukan perbaikan dari permasalahan yang ada sehingga peneliti mengidentifikasi dan merencanakan perbaikannya dengan melakukan tindakan proses pembelajaran di siklus II agar pembelajaran mentransformasi cerpen menjadi naskah drama siswa dapat meningkat sesuai nilai KKM pelajaran Bahasa Indonesia yaitu $\geq 75$. Proses pembelajaran siklus II pun masih menerapkan metode diskusi. Adapun hasil penelitian yang peneliti peroleh nilai siswa di siklus II meningkat. Siswa yang 
mendapatkan nilai $\geq 75$ mencapai 17 siswa $(77,27 \%)$. Sedangkan siswa yang belum lulus mendapatkan nilai $\geq 75$ adalah 5 siswa $(22,72 \%)$.

Untuk memberikan gambaran yang jelas atas pencapaian hasil penelitian yang telah meningkat pada siklus I dan siklus II dari hasil tes dan non tes dalam pembelajaran kemampuan mentransformasi cerpen menjadi naskah drama dapat dilihat melalui diagram 4.9 sebagai berikut.

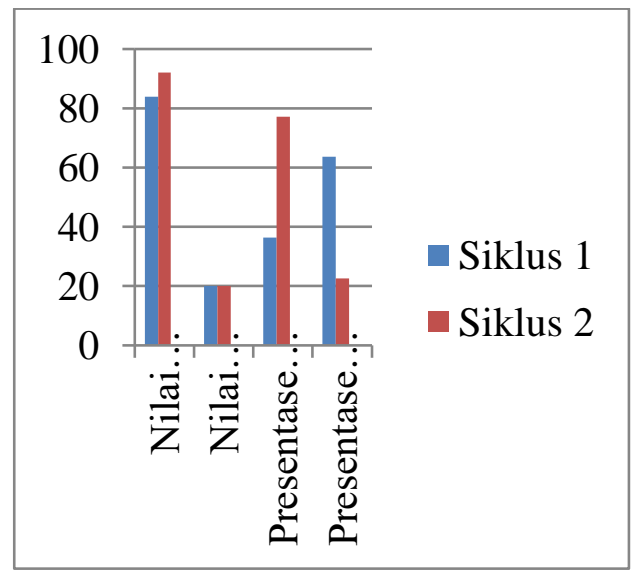

Berdasarkan penelitian yang telah dilakukan, proses pembelajaran yang menerapkan metode diskusi dapat meningkatkan kemampuan mentransformasi cerpen menjadi naskah drama siswa kelas VIII-A SMP Kristen Hosana tahun 2018/2019. Oleh karena itu, metode diskusi pada mata pelajaran Bahasa Indonesia dapat berperan penting untuk meningkatkan kemampuan mentransformasi cerpen menjadi naskah drama. Metode diskusi ini dapat mem berikan kesempatan kepada siswa untuk berdiskusi dengan teman mengenai materi pembelajaran mentransformasi cerpen menjadi naskah drama. Para siswa dapat saling bertukar pikiran, ide ataupun gagasan. Para siswa dapat saling memberikan saran terkait puisi yang akan mereka ciptakan. Oleh karena itu, penerapan metode diskusi dapat meningkatkan kemampuan menulis puisi siswa kelas VIII-A SMP Kristen Hosana.
Tahap tindakan yang telah dilakukan dalam penelitian ini adalah metode diskusi untuk meningkatkan kemampuan mentransformasi cerpen menjadi naskah drama. Pemilihan metode diskusi tersebut merupakan upaya untuk mengatasi permasalahan yang dihadapi guru dalam rangka meningkatkan kemampuan siswa dalam mentransformasi cerpen menjadi naskah drama. Model ini dapat menjadikan siswa lebih aktif saat proses pembelajaran berlangsung. Siswa dituntut untuk bekerja sama dalam tim untuk mentransformasi cerpen menjadi naskah drama. Siswa lebih berperan aktif saat peneliti yang beraktivitas sebagai guru memberikan kesempatan kepada siswa untuk berdiskusi dengan teman kelompoknya. Para siswa dapat berdiskusi satu sama lain terkait materi pembelajaran mentransformasi cerpen menjadi naskah drama.

Metode pembelajaran ini lebih menekankan peran siswa dalam pembelajaran, peneliti hanya berperan sebagai fasilitator dalam pembelajaran seperti mengondisikan keadaan pembelajaran yang sedang berlangsung di kelas. Siswa belajar memahami unsurunsur intrinsik dalam sebuah drama. Hingga hasil akhirnya siswa mampu mentransformasi cerpen menjadi naskah drama dengan memerhatikan unsur- unsur intrinsik yang dilakukan secara berkelompok, maupun secara individu yang dapat dilihat hasilnya dari penilaian pengerjaan tes kemampuan mentransformasi cerpen menjadi naskah drama siswa di setiap akhir siklus pembelajaran.

Model pembelajaran pada proses pembelajaran mentransformasi cerpen menjadi naskah drama telah dilaksanakan melalui beberapa tahap tindakan pembelajaran sebanyak dua siklus. Masing-masing siklus dilakukan dalam satu kali pertemuan. Pada siklus I alokasi waktu yang digunakan adalah 2x40 menit. Sedangkan pada siklus II alokasi waktu 
yang digunakan adalah $2 \times 40$ menit. Berdasarkan hasil observasi dan analisis dari siklus I dan II, pembelajaran mentransformasi cerpen menjadi naskah drama dengan menggunakan metode diskusi mengalami peningkatan terhadap hasil pembelajaran mentransformasi cerpen menjadi naskah drama siswa yang dilihat dari data hasil tes di akhir pembelajaran.

Namun berdasarkan hasil pengamatan peneliti dan guru dari lembaran observasi kegiatan guru dan kegiatan siswa pada siklus I dan siklus II terdapat beberapa aspek permasalahan yang telah diuraikan di tahap observasi sebelumnya. Lalu direncanakanlah proses perlakuan perbaikan dalam suatu tindakan di setiap siklusnya. Persentase KKK di siklus I rendah, yaitu hanya $59,37 \%$. Hal ini karena masih banyak siswa yang tidak mengikuti instruksi peneliti untuk mempelajari ulang materi pembelajaran yang telah disampaikan, masih banyak siswa yang tidak serius mengerjakan tugas yang telah diberikan. Kebanyakan dari mereka malah asyik bercerita.

Pada proses pembelajaran di siklus II masih menerapkan metode diskusi dan mulai mengalami peningkatan. Persentase KKK di siklus II mencapai, 78, 12\%. Hal ini karena hampir seluruh siswa mulai mengikuti instruksi peneliti untuk mempelajari ulang materi pembelajaran yang telah disampaikan, banyak siswa yang mulai serius mengerjakan tugas yang telah diberikan. Sehingga proses pembelajaran yang berlangsung mengalami kemajuan, sehingga terbukti terjadi peningkatan kemampuan mentransformasi cerpen menjadi naskah drama pada siswa.

Pada akhirnya guru dan peneliti menyatakan bahwa proses pembelajaran dalam menerapkan metode diskusi untuk meningkatkan kemampuan mentransformasi cerpen menjadi naskah drama siswa VIII-A SMP Kristen Hosana
Medan sudah berjalan dengan baik dan lancar. Terlihat dari hasil penilaian di siklus I dan siklus II meningkat sesuai dengan $\mathrm{KKM} \geq 75$ dan nilai persentase KKK siswa dengan nilai $\geq 75 \%$. Dengan demikian, dapat disimpulkan bahwa berdasarkan rumusan masalah di Bab I dan hipotesis tindakan pada Bab II telah dinyatakan dan dipaparkan pada hasil penelitian di Bab IV ini, bahwa penerapan metode diskusi dapat meningkatkan kemampuan mentransformasi cerpen menjadi naskah drama siswa VIII-A SMP Kristen Hosana Medan tahun 2018/2019. Dalam hal tersebut dapat membantu guru bidang studi Bahasa Indonesia untuk lebih aktif lagi dalam mengelola kondisi kelas.

\section{SIMPULAN}

Berdasarkan hasil dan pembahasan dalam penelitian ini dapat disimpulkan sebagai berikut.

1. Proses pembelajaran kemampuan menulis puisi siswa VIII-A SMP Kristen Hosana tahun 2018/2019 pada tahap prasiklus siswa masih kurang memahami materi pembelajaran drama. Dengan penerapan metode diskusi yang diberikan pada siswa pada tahap siklus I, Siswa dapat memahami materi pembelajaran mentransformasi cerpen menjadi naskah drama. Karena siswa dapat saling berdiskusi dengan teman kelompoknya, saling bertukar ide, ataupun gagasan. Siswa lebih giat untuk mengulang kembali materi yang telah diberikan oleh guru, dan tertarik untuk belajar mentransformasi cerpen menjadi naskah drama. Pada tahap siklus I ini peneliti menggunakan media teks sebagai media pembelajaran dengan alokasi waktu 2x40 menit.

2. Hasil kemampuan mentransformasi cerpen menjadi naskah drama siswa VIII-A SMP Kristen Hosana tahun 2018/2019. Hasil penilaian tes kemampuan mentransformasi cerpen menjadi naskah drama dengan menggunakan metode diskusi siklus I 
persentase KKK mencapai $36,36 \%$ atau 8 siswa yang tuntas. Pada siklus II melalui penerapan metode diskusi dapat meningkatkan kemampuan mentransformasi cerpen menjadi naskah drama siswa dengan persentase KKK siswa memperoleh $77,27 \%$ atau 17 siswa yang tuntas.

3. Peningkatan hasil pembelajaran kemampuan mentransformasi cerpen menjadi naskah drama dengan menerapkan metode diskusi pada siswa VIII-A SMP Kristen Hosana tahun 2018/2019 meningkat. Terbukti dari persentase KKK hasil tes kemampuan mentransformasi cerpen menjadi naskah drama siswa pada siklus I ke siklus II sebesar 40,91\%. Berdasarkan data tersebut, dapat disimpulkan bahwa siklus I ke siklus 2 mengalami peningkatan.

\section{DAFTAR PUSTAKA}

Arikunto, S dkk, 2012. Penelitian Tindakan Kelas. Jakarta : Bumi Aksara.

Aqib,Z dkk, 2008. Penelitian Tindakan Kelas. Jakarta : Bumi Aksara.

Dalman, H, 2014. Keterampilan Menulis. Jakarta : PT. Raja Grafindo Persada.

Endaswara, Suwardi. 2014. Metode Pembelajaran Drama (Apresiasi,Ekspresi, dan Pengkajian). Yogyakarta : CAPS.

Fitriani, Oktavia. 2016. "Peningkatan keterampilan menulis naskah drama satu babak dengan tehnil quantum writing siswa kelas VIIID SMP Negeri 3 Sewon. Skripsi pendidikan bahasa dan sastra Indonesia, fakultas bahasa dan seni. UNY : tidak diterbitkan.
Ika. 2011. "Peningkatan keterampilan menulis cerpen melalui media berita dengan metode latihan terbimbing pada siswa kelas X.3 SMA Negeri 1 Rembang Purbalingga". Skripsi Pendidikan Bahasa dan Seni. UNY: tidak diterbitkan.

Istarani. 2012. Kumpulan 39 Metode Pembelajaran. Medan : CV. Iscom Medan.

Kosasih, E. 2016. Apresiasi Sastra Indonesia. Jakarta : Nobel Edumedia.

Kurniasih Imas dan Sani Berlin, 2015. RagamPengembangan Model Pembelajaran. Jakarta: Kata Pena

Nurhadi, Ardhian. 2016. "Peningkatan keterampilan menulis naskah drama dengan media pembelajaran stop motion untuk siswa kelas VIIIA SMP N 1 Semanu Gunungkidul". Skripsi pendidikan bahasa dan sastra Indonesia, fakultas pendidikan bahasa dan sastra Indonesia. UNY : tidak diterbitkan.

Pratiwi Yuni dan Frida Siswiyanti.2016. Teori Drama dan Pembelajarannya. Yogyakarta: Ombak

Tarigan, Henry Guntur. 2008. Menulis Sebagai Suatu Keterampilan Berbahasa. Bandung: Angkasa Bandung.

Winingsih, Rini. 2011. "Peningkatan keterampilan menulis naskah drama dengan media boneka (Stick Wayang Orang) pada siswa kelas VIII-B SMP N 2 Sentolo. Skripsi pendidikan bahasa dan sastra Indonesia, fakultas bahasa dan seni. UNY : tidak diterbitkan. 